\title{
Not in front of the children? An analysis of sex on screen in Italy
}

\author{
Delia Chiaro \\ University of Bologna at Forlì
}

Despite the fact that both state owned (RAI) and privately owned (Mediaset) Italian television channels habitually adopt scantily dressed women in provocative poses to fulfill a purely decorative function on daytime television, a closer look at Italian TV reveals that it is far less liberated than it seems. In fact, in stark contradiction to the apparent unrestraint of autochthonous studio productions, references to sex and sexuality in imported fictional products tend to be severely mitigated in their translated forms. Furthermore, it also appears that sexual behaviour beyond traditional male/female 'mainstream' sexual practices becomes increasingly taboo in translation, as they too are either toned down or totally eliminated. Relegated to cable and satellite channels or late-night/early morning viewing on one of the privately owned Mediaset channels, programs containing very explicit sexual content such as US produced 'Sex and the City' are moderated quite significantly for Italian audiences, not only in terms of the pervasive use of strong, taboo language, but also for explicit references to a variety of sexual practices.

This paper will discuss the norms which govern the translation of 'adult' materials for Italian TV both from an examination of the linguistic content of the programs themselves and from the point of view of operators involved in the dubbing process.

\section{Introduction: taboo terms in translated productions}

Issues regarding censorship and screen translation have been discussed by several authors. Studies by Chiaro (1996 and 2000a); Pavesi and Malinverno (2000) and Hargan (2006) reveal that taboo terms and coarse language are either suppressed or reduced in Italian dubbed versions of films; findings by Vandaele (2002) display the mitigation of allusions to promiscuity, adultery and suicide in subtitled versions of the films of Billy Wilder in Francoist Spain; while Bianchi's study of the Italian translation of Buffy the Vampire Slayer (forthcoming) and Bucaria's work on US television series (this issue) demonstrate that present day democratic Italy tends to liberally tone down not only sexual references, but even terms of insult which have become de-semantised (cf. Bucaria's discussion of the abusive item 'moron'). Needless to say, such extreme interference with the original versions leads to (sometimes drastically) different narratives in their translated forms not only in terms of recounting and characterization, but also, and perhaps more significantly, in terms of style cf. Munday (2006) and Bucaria (this issue). 
Sex has become the essential ingredient of many series that are produced in the USA and subsequently exported to Europe. Sex and the City (from now onwards $S a t C$ ) is a case in point. However, matters pertaining to sex are pervasive in numerous other series imported from North America. Ally MacBeal, Nip/Tuck, Desperate Housewives, Big Love and The L Word are just a few examples of series that contain explicit sexual subject matter, namely in terms of unequivocal references to a wide spectrum of sexual activities which often go beyond heterosexual sexual intercourse and the patent naming of genitalia. Over and above the verbal code, visually too, such series include scenes containing nudity as well as explicit sexual behaviour. Given that both visual and verbal sexuality has been traditionally mitigated for Italian audiences, this essay sets out to explore how such alleviation is achieved. Following a brief summary of norms governing censorship on screen in Italy, the easing of sexual features in the dubbed version of $\mathrm{SatC}$ will be examined in detail. In particular, the strategies involved in transposing three salient verbal sexual denotations into Italian will be examined; namely the designation of genitalia; references to sexual intercourse; and references to what have been labeled, 'additional sexual practices' i.e. practices which exclude coition such as oral/anal sex; masturbation; sadomasochism etc. Subsequently, a discussion of the dialogues accompanying scenes containing explicit sexual activity will illustrate how a significant adaptation of the original dialogue can reduce the edge from such scenes, severely moderating what was their hitherto racy quality. Although it could be argued that translational choices may also depend upon the technical constraints of dubbing, the principal limitation being the issue of lip-synchronization, the fact that mitigation occurs consistently in the presence of references to taboo subject matter, overrules this possibility.

\section{Censorship and translation in Italy}

In Italy, a board of censors controls the suitability of full length films to be screened in theatres with regard to whether a product is suitable for adults only, for those who are over the age of fourteen; whether it requires parental guidance during viewing or whether it is appropriate for wider 'family viewing'. Despite awareness of the existence of a similar body (or bodies) governing television programs, the author has to date found no concrete evidence of such an organization. When the product that is about to broadcast contains scenes and language which might be inappropriate for children, state owned RAI channels usually send out a verbal warning prior to screening. On the other hand, privately owned Mediaset channels adopt a system of symbols at the corner of the screen; i.e. a red circle containing the silhouette of a grown-up indicating that the program is uniquely for adult viewing, an orange circle with the profile of an adult holding a child's hand, indicating fitness for viewing with parental guidance and green with the outline of a child indicating fitness for family viewing. Furthermore, full-length feature films which had been previously deemed appropriate for over-fourteens by the board of censors can only be screened on television in seconda serata or rather, after the 22:30 watershed. Films certified for adult-only viewing, cannot be aired at all. 
However, where and by whom such decisions for television are made, to date remains unclear.

Obviously, broadcasting a program late at night implies a smaller audience, which means that television companies are willing to pay producers a lower price than that which is normally paid for a product that can be screened during prime time and, therefore, to a wider audience. Not only, but a program screened late at night is in turn likely to gain lower profits in terms of advertising. Industries investing in television marketing do so in order to attract large numbers of possible buyers of their products and, it stands to reason, that they will want their wares advertised at times when most people will be watching TV. Thus, it may not be entirely unlikely that television companies require translators to censure programs containing taboo language so that they can then be freely screened during prime time. Furthermore, many successful US series (e.g. House; Grey's Anatomy; Desperate Housewives, Lost, etc.) are usually premiered - and hence commissioned for translation - by one of the Fox (satellite) channels before being sold the following season to mainstream TV channels inclusive of translation ${ }^{1}$. So, it would appear that commissioners and translators need to bear in mind the issue of future wider and more heterogeneous RAI and Mediaset audiences who will be exposed to the same product once screened during earlier time spans.

Likewise, with regard the use of censorship via translation, stories circulate regarding the existence of a 'black-list' of what are considered English words and references which are strictly taboo on Italian TV, although no real evidence of such a list can be found, thus relegating such a suggestion to mere hearsay; (see interview with Luigi La Monica, dubbing director of the program's fifth and sixth series, in 3.2$)^{2}$.

\section{Sex and the City}

\subsection{Sex and the City in the USA}

SatC consists of ninety-eight, 25-30 minute long episodes, which were originally broadcast between 1998 and 2004 by American pay-TV channel HBO (Time Warner Entertainment Company), and then exported world wide, including to Italy, where it arrived in 2000 . The series was inspired by a book of the same title written by journalist Candace Bushnell, who was originally responsible for the homonymous column in the New York Observer. Column, book and series recount stories of modern day relationships in elitist New York that are based on sex, love and friendship - but, as the title suggests, above all on sex. In particular, the series recounts the sentimental and sexual relationships of four thirty-something girlfriends, Carrie Bradshaw (aka Bushnell/narrator/journalist); Miranda Hobbes; Samantha Jones and Charlotte York. The program is particularly pertinent for a study on censorship and translation because of the highly risque nature of both visual and verbal content. In fact, Carrie Bradshaw defines herself as a "sexual anthropologist" and her column involves research on a number of sex-related subject matters which extend from the issue of sex without emotional ties to subjects 
such as masturbation, ménages à trois, sadomasochism and beyond. In the opening credits to each episode we read: "Carrie Bradshaw knows good sex, and isn't afraid to ask". And, Bradshaw carries out her research in the field, in more ways than one.

In 2004, HBO sold the series to TBS (Turner Broadcasting System Inc.), a society which is part of the Public Broadcasting Service that also runs Cartoon Network, TNT, Boomerang and CNN news. Unlike HBO which is totally free of the shackles of censorship, TBS is obliged to respect the rules of the Federal Communications Commission, an independent government agency founded by the 1934 Communications Act that has the precise task of regulating interstate and international communication. The change from Pay TV to mainstream was significant as it meant that the series could now be seen by many more than the previous 26 million HBO subscribers. Thus, the series which had originally been screened uncut, was now censored. Many nude scenes were removed, as were dialogues containing explicit sexual content. Furthermore, when being broadcast by HBO, SatC would go out between 20.00 and 00.30 according to time zones, while at TBS, broadcasting began an hour later, at 21.00 Eastern time, a watershed which would supposedly automatically select more mature audiences.

Ponza (2004) exemplifies the politics of TBS by illustrating the type of censorship employed upon the dialogues during their relocation from HBO. Both examples in Tables 1 and 2 occur in sexually explicit bedroom scenes in which the speakers are in a state of undress.

Table 1

\begin{tabular}{|c|c|}
\hline \\
\hline \multicolumn{2}{|c|}{$\begin{array}{l}\text { Alexander and Charlotte are in bed, clearly engaged in sexual intercourse. While } \\
\text { Alexander climaxes he cries out: }\end{array}$} \\
\hline TBS & $\mathrm{HBO}$ \\
\hline "You stupid bitch, you nasty whore!" & $\begin{array}{l}\text { "You fucking bitch, you fucking } \\
\text { whore!" }\end{array}$ \\
\hline
\end{tabular}

Table 2

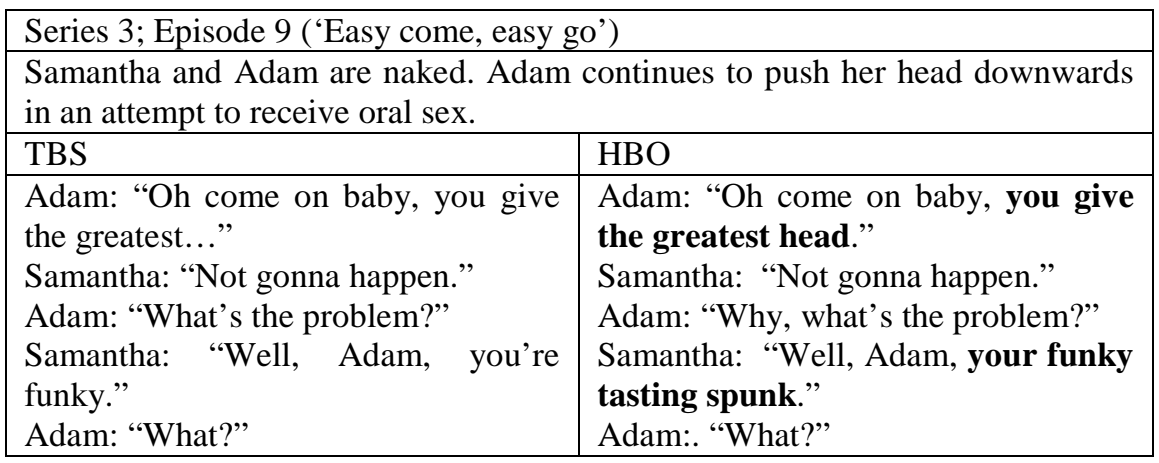




\begin{tabular}{|c|c|}
\hline $\begin{array}{l}\text { Samantha: "You heard me, funky." } \\
\text { Adam: "Man, I have heard some far } \\
\text { out excuses but this one takes the } \\
\text { cake." } \\
\text { Samantha: "Excuse me, I resent that." } \\
\text { Adam: "Come on, it's easy." } \\
\text { Samantha: "Easy! You have no idea } \\
\text { what we're dealing with. Honey, they } \\
\text { don't call it a job for nothing." } \\
\text { Adam: "Come on, it can't be that } \\
\text { bad." } \\
\text { Samantha: "I'll make a deal with you. } \\
\text { You try it. If you're fine with it, I'll } \\
\text { be fine with it. Take it or leave it." }\end{array}$ & $\begin{array}{l}\text { Samantha: "You heard me, your } \\
\text { spunk is funky." } \\
\text { Adam: "Man, I have heard some far } \\
\text { out excuses for not giving head, but } \\
\text { this one takes the cake." } \\
\text { Samantha: "Excuse me?" } \\
\text { Adam: "You're one of them two } \\
\text { blow job chicks, You put blow jobs } \\
\text { in the coming attractions that I'll } \\
\text { never see in the actual movie." } \\
\text { Samantha: "I resent that. I love giving } \\
\text { head." } \\
\text { Adam: "Come on, give me a little BJ, } \\
\text { up and down a couple times, you're } \\
\text { done, it's easy!" } \\
\text { Samantha: "Easy? You men have no } \\
\text { idea what we're dealing with down } \\
\text { there. Teeth placement, and jaw } \\
\text { stress, and suction, and gag reflex, } \\
\text { and all the while bobbing up and } \\
\text { down, moaning and trying to breathe } \\
\text { through our noses. Easy? Honey, they } \\
\text { don't call it a job for nothin'! Having } \\
\text { said all that, with the right man, it can } \\
\text { be fabulous. That is, unless the man } \\
\text { in question has spunk that's like a trip } \\
\text { on the rotten egg buffet." } \\
\text { Adam: "Come on, it can't be that } \\
\text { bad." } \\
\text { Samantha: "I'll make a deal with you. } \\
\text { You try it. If you're fine with it, I'll } \\
\text { be fine with it." } \\
\text { Adam: "I can't do that. It's gay." } \\
\text { Samantha: "It's not gay if it's you. } \\
\text { Take it or leave it." }\end{array}$ \\
\hline
\end{tabular}

The example in Table 1 shows how the term 'fucking' is diluted to the more neutral 'stupid' and 'nasty' which teamed respectively with 'bitch' and 'whore', substantially tone down the overall effect. However, the dialogue in Table 2 exemplifies more radical deletions. The original references to oral sex and effluvia present in the HBO screenings disappear in the TBS version leaving only a single allusion in the line "they don't call it a job for nothing" although, with the deletion of the references to fellatio (i.e. "blow"), the insinuation is totally lost. Thus, despite what can actually be seen on the screen, (a naked couple cavorting in bed) the milder dialogue turns the scene into something far less audacious compared to the original. And this is similar to the effect of what often occurs in the Italian inter- 
lingual translation too (see 3.2). Furthermore, Adam's comment on "two blow job chicks" and Samantha's long and meticulous description of the technicalities of oral sex are deleted, as is the closing reference to homosexuality. And with them vanish a series of "good lines" (Chiaro; forthcoming a), the purpose of which is to produce laughter in the recipient (for a more detailed discussion on the loss of humorous effect see Bucaria, this issue). In addition, the titles of the episodes also often contain good lines. The two episodes from which the previous examples were taken are entitled 'Are we sluts' and 'Easy come, easy go'. The translations respectively become Quanti uomini sono troppi? (How many men are too many?) and C'è chi va e c'è chi viene (Some people go and others come). While the translation does contain a taboo connotation, it is very mild if compared to the original title: 'Are we sluts'.

\subsection{Sex and the City in Italy}

Privately owned channel $L A 7$ first broadcast SatC between 2000 and 2004, firstly from midnight onwards and subsequently from 22.45 . At the time of writing, the series is being intermittently repeated on Canale Jimmy, a satellite channel which is part of the SKY package. Scheduling on this channel is less rigid that $L A 7$, with the programs going out after 19.30 with nightly re-runs. Furthermore, the Italian DVDs of the series, bear the parental guidance symbol.

The first three series of SatC were translated, adapted and dubbed by Cast Doppiaggio while $C V D$ took over the translation/dubbing process for the last three seasons. ${ }^{3}$ From an interview with Luigi La Monica ${ }^{4}$, director of the dub of the part of the fifth and sixth and series (and also the Italian voice of Mr Big, Carrie's illicit lover throughout ${ }^{5}$ ) it emerges that there is no such thing as a 'black list' of taboo words (cf. 2). Furthermore, according to La Monica, censorship is completely self-imposed by operators involved in the dubbing process. In the episodes he directed, he himself deliberately moderated all that he considered to be taboo because "A certain type of strong language is likely to offend Italians" (translation DC.) Furthermore, La Monica also believes that "Americans generally use more bad language than Italians" (translation DC) and verbal equivalence would have in some way falsified the Italian, the speakers of which, in his opinion, are less used to using and hearing strong language. Thus, an experienced dubbing director like La Monica, only inserts strong language in the dub when he deems it necessario or "necessary" (translation DC). When asked how he decides when exactly strong language is necessary in Italian and when it is not, La Monica replied that this depends upon the context in which the utterance containing the taboo item occurs. In other words, inserting or not inserting taboo elements also depends on elements such as facial expressions and body language of other participants in a particular scene, as well as their verbal responses. When the context of the situation is reasonably safe, he believes that toning down risque elements can quite easily be achieved without the audience noticing otherwise. Nevertheless, Roberta Pifferi ${ }^{6}$, a freelance dubbing-translator working in Rome claims that: 
There is no precise answer to your question (i.e. who decides what and how items are censored). Translational decisions regarding references to sex and expletives are taken as they occur and instructions are given by the television channel commissioning the translation. For example, in programmes like The Simple Life, Beauty and the Geek and Girls from the Playboy Mansion - as well as thousands of others - the translators are allowed to leave taboo items as they are, even if edulcoration is always preferable. In other, more extreme cases, like the one I came across less than a month ago - Extreme Russia - adaptors like me have to transform themselves into authors (speaker's emphasis) and invent whole utterances in order to censure references to sex. [...] However, generally speaking, the channel gives us the target to aim at, and according to this, instructions as to how to treat more delicate content. On the whole, I'd say that allusions are generally kept while explicit references, that are sometimes really strong (Americans are experts at those!) are deleted. (Personal communication, translation DC) ${ }^{7}$

However, unlike what occurred in the series' passage from HBO to TBS, in which substantial cuts in both dialogue and visuals can be witnessed, for Italian consumption, only the dialogues underwent censorship, leaving images totally intact. Yet, arguably, the mitigated dialogues succeed in taming what would otherwise be audacious visuals. For example, the exchange discussed previously (Table1) becomes Fottuta puttana; fottuta troia! for "You fucking bitch, you fucking whore!". As discussed by Galassi (2000), the term fottuta is quite unrepresentative of a naturally occurring Italian taboo word. Furthermore Antonini and Chiaro (2005) empirically demonstrate how a large sample of Italians recognize the term (in a sexual connotation) as an item belonging to televised Italian alone, and that they did not think that the term was likely to occur in natural everyday conversation.

Another example of the mitigation of taboo obtained through the insertion of unrepresentative Italian is illustrated in Table 2a, in which the term 'spunk' (cf. Table 2) is replaced with the word bianco meaning literally 'white'.

Table 2a Italian dub and back-translation of dialogue in Table 2 ('Are we sluts?' C'è chi va e c'è chi viene.) 


\begin{tabular}{|c|c|}
\hline Italian dub & Back- translation \\
\hline $\begin{array}{l}\text { Adam: ...dai, i tuoi pompini sono i } \\
\text { migliori. } \\
\text { Samantha: Non ci penso proprio. } \\
\text { Adam: Scusa, qual'è il problema? } \\
\text { Samantha: Bene, Adam, il tuo bianco } \\
\text { ha un sapore nauseabondo. } \\
\text { Adam: Cosa? } \\
\text { Samantha: Il tuo bianco fa schifo! } \\
\text { Adam: Bianco? } \\
\text { Samantha: Speme, sperma, lo schizzo } \\
\text { della felicità fa schifo! } \\
\text { Adam: Scuse per non fare dei } \\
\text { pompini, ne ho sentite, ma questa le } \\
\text { batte tutte! } \\
\text { Samantha: Come dici? } \\
\text { Adam: Sei una da due pompini e } \\
\text { basta. Ne metti due nei trailer e poi la } \\
\text { fregatura è che nel film non ce ne sono } \\
\text { altri. } \\
\text { Samantha: No, mi disdico, Adam. Io } \\
\text { adoro fare i pompini. } \\
\text { Adam: Allora vieni qui e fammi un } \\
\text { paio di veloci lavoretti di bocca, su e } \\
\text { giù con la testa ed è finita, è facile. } \\
\text { Samantha: Facile! Voi non avete idea } \\
\text { di cosa ci aspetta ai piani bassi. } \\
\text { Otturazioni a rischio, mascella slogata, } \\
\text { ipersalivazione, conati di vomito ed un } \\
\text { agitare la testa su e giù mentre } \\
\text { gemiamo e cerchiamo di respirare dal } \\
\text { naso. Facile? Se si chiama 'lavoro di } \\
\text { bocca' ci sarà un motivo. Ora, detto } \\
\text { questo, con l'uomo giusto è } \\
\text { meraviglioso. Ma questo quando lo } \\
\text { sperma dello stallone in questione } \\
\text { non ha vinto il primo premio del } \\
\text { concorso delle uova marcia. } \\
\text { Adam: Non può essere così male. } \\
\text { Samantha: Facciamo un patto. Tu lo } \\
\text { assaggi e se va bene a te, allora va } \\
\text { bene anche a me. } \\
\text { Adam: Non posso farlo. E da gay. } \\
\text { Samantha: Caro, non è gay se è roba } \\
\text { tua. }\end{array}$ & $\begin{array}{l}\text { Adam: ...come on, your blow jobs } \\
\text { are the best. } \\
\text { Samantha: I don't think so. } \\
\text { Adam: Sorry, what's the problem? } \\
\text { Samantha: Well, Adam, your white } \\
\text { has a nauseous taste. } \\
\text { Adam: What? } \\
\text { Samantha: Your white makes me } \\
\text { sick! } \\
\text { Adam: White? } \\
\text { Samantha: Your seed, sperm, spurt } \\
\text { of happiness makes me sick! } \\
\text { Adam: I've heard some excuses for } \\
\text { not wanting to give head, but this } \\
\text { beats them all! } \\
\text { Samantha: Excuse me? } \\
\text { Adam: You are a two blow job girl } \\
\text { and that's it. You put two in the trailer } \\
\text { and then rip me off in the main feature } \\
\text { because there are no more. } \\
\text { Samantha: I disagree Adam. I love } \\
\text { giving head. } \\
\text { Adam: Then come here and do a cou- } \\
\text { ple of little jobs with your mouth, } \\
\text { up and down with your head and } \\
\text { that's it, it's easy. } \\
\text { Samantha: Easy? You have no ideas } \\
\text { what we get on the lower floors. Fill- } \\
\text { ings are at risk, dislocated jaw, hyper- } \\
\text { salivation, gagging while shaking our } \\
\text { heads up and down moaning and } \\
\text { breathing through our noses at the } \\
\text { same time. Easy? If it's called a } \\
\text { mouth job there must be a reason. } \\
\text { Having said that, with the right man it } \\
\text { can be wonderful. But only when the } \\
\text { sperm of the stallion in question } \\
\text { hasn't won first prize in the bad eggs' } \\
\text { contest. } \\
\text { Adam: It can't be that bad. } \\
\text { Samantha: Let's make a deal. You } \\
\text { taste it and if it's ok with you, it's ok } \\
\text { with me too. } \\
\text { Adam: I can' do that, it's gay. } \\
\text { Sam.: Honey, it's not gay,if it's yours. }\end{array}$ \\
\hline
\end{tabular}


It is clear from the fact that the scene is complete and uncut, that Fox Italia adapted the program from the HBO version. However, the language is, in places, substantially moderated, although not to the extent to which the dialogue was cut by TBS. For example, the Italian term for fellatio that comes closest in terms of register to that of 'giving head', is respectively pompino and this term does occur three times in the translation. However, reduction in the dialogue occurs for two other sexually related items. Firstly, in reference to the term 'spunk', the translation adopts the noun ( $n . b$. not the adjective) bianco; literally 'white'. Normally bianco is an adjective, and although it can be used nominally in a phrase such as 'egg white', it is highly unlikely for an Italian speaker to denote sperm as 'a white'. But, on the one hand, if the choice of bianco may seem weak in comparison to the unmistakable meaning of 'spunk', it does give Adam a very good excuse for not understanding what Samantha is talking about. And, subsequently, a sort of compensation occurs when she spells out that bianco is speme / seed; sperma /sperm and lo schizzo della felicità / 'the spurt of happiness'. Secondly, another term for fellatio, namely: 'blow job' is translated with lavoro di boccaliterally 'mouth job'. Although, the term is, to say the least, unusual, i.e. pompino appears to be the more common term in Italian, Google contains 84,700 hits for lavoro di bocca. Could it be that the term has entered the language via Italian dubbese? ${ }^{8}$

\section{The mitigation of references to sex through translation}

Despite the fact that only the dialogues are manipulated in the Italian dub leaving visuals identical to the source, Italian $\mathrm{SatC}$ is considerably dissimilar from the original. And over and above the actual words, phrases and dialogues uttered, a very striking difference, and, I would argue, a significant instance of censorship, can be found in the tone of the actors' voices. Much, although not all, of the racy dialogue is mitigated, in the sense that instances of taboo are often replaced with what would be commonly considered as more acceptable discourse.

Supporters of the subtitling camp traditionally use the fact that the voices of the original actors give place to the totally new voices of the dubbing actors, as one of their strongest arguments against dubbing. Without wishing to enter into the argument of the superiority of either translational mode (cf. Díaz Cintas 1999), and especially since audiences tend to prefer the mode to which they are accustomed "...viewers are creatures of habit" (Ivarsson 1992: 66), it cannot be denied that features such as voice quality and tone are vocal attributes which do indeed contribute to the shaping of characters and to the construction of meaning. Thus, traditionally, a number of big screen actors, directors and producers who care about the way their films are exported, have actually been involved in choosing dubbing actors. Woody Allen and Stanley Kubrick are examples of actor/directors actively involved in the dubbing process of their films and Disney/Buena Vista products are well known for the similarity of voice quality of cartoon characters across dozens of languages, again displaying concern for non-English speaking 
audiences. However, on the whole, the tone of the four main characters in Italian SatC is undoubtedly more jaunty and spry than that of the characters in the English version. For example, the dry irony of straightforward Miranda and the cool self-assuredness of breathy, sex-crazed Samantha are ill matched by their jolly Italian counter-voices. Furthermore, the Italian dialogues are uttered too clearly. In other words, the educated New Yorkese of the four protagonists is substituted with eloquently uttered Tuscan-Roman Italian (for a detailed discussion of this phenomenon see Pavesi 1994 and 1996). If we sum the absence of high idiomaticity and the localization of numerous socio-cultural references to New York culture to the new audio, over and above the words, the result is truly a different effect. Firstly, the Italian dub significantly modulates the ever present white noise of New York's streets, restaurants, clubs and parties, rendering this version generally quieter and more sedate. Secondly, owing to different post-production conventions in the USA, which tend to leave actors' voices sounding unclear, almost impure, the 'quietness' of the Italian dub is somewhat striking. In the original, it is almost as though actors have full permission to slur some words and drop the endings off others, just as happens in real life conversation. With the dub, the series appears to have lost the acoustic impurity of the original. (Deliberate?) non-clarity is replaced with perfectly eloquent Italian. A good example of this phenomenon can be found in the dub of Brokeback Mountain (Ang Lee 2005, USA). Over and above the inevitable suppression of the particular variety of English spoken by the actors, the Italian dub has a clarity which is missing in the original, that, while certainly helping audiences understand every single word the characters utter, completely distorts a film in which mis-communication is an essential element of the plot as a whole. Something similar occurs in SatC. The clatter of New York city is hushed, the lively chatter of the four protagonists is understated. In the episode entitled 'Politically Erect' (Season 2; Episode 2) Carrie is acting as a judge at a fund raising male striptease competition. As each stripper takes the floor and begins to undress, a presenter tries to give out personal information about him, such as name, star sign and hobbies, above the noise. But, the noise in the club is deafening, music is playing loudly and the female audience is cheering the strippers on with hysterical screaming. Despite the fact that the presenter is yelling at the top of her voice, it is very difficult to discern what she is actually saying. In the Italian version, the surrounding noise is toned down, and every word the announcer makes is emitted loudly and clearly. I would like to argue that this is also a form of mitigation. The raucous comments of the women encouraging the strippers disappear as does the excited tone of the presenter. What results is sedate (rather than racy) dialogue.

\subsection{The dialogues}

The norm for translating all that is taboo in the dub seems to follow the conventional rule of either mitigation, substitution or deletion. I have chosen to adopt the term 'conventional' as the translation of taboo appears to have much in common with the translation of other notoriously complex features beyond the taboo, such as Verbally Expressed Humour (VEH, which, for example, requires similar strate- 
gies in its transfer across languages cf. Chiaro 2000a). An instance of VEH can be substituted with a different example in the target language or it can be deleted. Of course, VEH does not require mitigation, unless it contains risqué material, but mitigation is precisely what does occur when the source gag is substituted with an idiomatic expression thus causing the joke to disappear and the VEH is thus mitigated into a non humorous expression (ibid.). However, when translating VEH, compensation is sometimes adopted too. Compensation occurs when, for example, an instance of wordplay which is especially difficult to translate is omitted yet replaced with a fresh example of VEH inserted elsewhere in the text where the source text had no such occurrence. With regard to taboo, unlike VEH, for obvious reasons, the strategy of compensation, in which an item which causes translational difficulty is eliminated, but replaced elsewhere rarely occurs in the translation of taboo, in fact, close examination of the entire six series, only revealed two examples of compensation (see 4.1.1.1).

The examples of taboo items in this series are literally countless. Each episode is packed not only with allusions and innuendo, but above all with explicitly stated sexually related subject matter and the words and expressions that accompany it; in other words, what, to many people, may seem unmentionable language, objects, and above all, practices. And naturally, there are also numerous examples of abusive language and expletives. Space does not allow for the discussion of every single occurrence, thus the examples chosen for discussion have been chosen firstly, for their pertinence (i.e. some kind of reference to explicit sexual subject matter), but more importantly, quite randomly for their representativeness of similar examples in other episodes across the six series (i.e. they occurred frequently across the series).

What follows are detailed analyses of translational strategies adopted for naming genitalia; sexual intercourse and a range of what have been vaguely labeled 'additional sexual practices'.

\subsubsection{Items related to genitalia}

\subsubsection{Male genitalia}

The term which the four protagonists mostly adopt to refer to the penis is either 'penis' itself, or more frequently, 'dick'. Although, the stronger term, 'cock' does occur, it is quite rare. On the other hand, the term 'dick' is used liberally in almost every episode, as is the more refined term 'penis'. Thus, given that in terms of strength (and taboo) in English the three terms occur on a hypothetical scale stretching from 'penis' (neutral), to 'dick' (vulgar), and finally 'cock' (very vulgar ) - although Merriam Webster defines both 'dick' and 'cock' as 'usually vulgar penis" (my italics) and the OED, both terms as "slang penis", it should follow that the dub will adopt an equivalent scale of Italian usage. Yet, in the translation, generally, a reference to male genitalia is either toned down to the term uccello (literally 'bird', and not as vulgar as either 'dick' or 'cock') or diluted even further to the pronoun 'it' - lo. Only twice, is either term translated with the exact Italian 
term in such circumstances, namely: cazzo, and arguably, it appears to have been inserted in a compensatory manner (Table 4).

Thus, the Italian scale could be pene (neutral) / lo (neutral pronoun); $u c$ cello (mildly taboo and not especially vulgar); cazzo (taboo and vulgar).

Table 3: Mitigation of items referring to male genitalia

\begin{tabular}{|c|c|}
\hline \multicolumn{2}{|c|}{$\begin{array}{l}\text { 1. 'The Power of Female Sex' Il giusto scambio (Series 1; Episode 5) } \\
\text { Samantha's latest lover has a small penis. }\end{array}$} \\
\hline $\begin{array}{l}\text { Samantha: "He has a tiny little penis } \\
\text { but he knows exactly how to use it." }\end{array}$ & $\begin{array}{l}\text { Samantha:Ce lo ha piccolissimo ma } \\
\text { lo sa usare molto bene. }\end{array}$ \\
\hline \multicolumn{2}{|c|}{$\begin{array}{l}\text { 2. 'Bay of Married Pigs' Singles \& Sposati (Series 1; Episode 3) } \\
\text { Carrie is flashed by her friend's husband; his wife confronts him. }\end{array}$} \\
\hline $\begin{array}{l}\text { "Did Carrie see your dick in the } \\
\text { hall?" }\end{array}$ & Carrie ti ha visto l'uccello? \\
\hline \multicolumn{2}{|c|}{$\begin{array}{l}\text { 3. 'The Awful Truth' La verità fa male...? (Series } 2 \text {; Episode } 2 \text { ) } \\
\text { Miranda is using strong language to a lover who requires excitement through } \\
\text { 'dirty talk'. }\end{array}$} \\
\hline $\begin{array}{l}\text { Miranda: "I just love having my hand } \\
\text { around your cock" } \\
\text { Lover: "I love you saying cock." } \\
\text { Miranda : "Cock !... Cock ! Cock ! } \\
\text { Cock ! Cock!" }\end{array}$ & $\begin{array}{l}\text { Miranda: Mi piace la mia mano } \\
\text { intorno al tuo uccello. } \\
\text { Lover: Mi piace quando dici uccello. } \\
\text { Miranda: Uccello!... Uccello! } \\
\text { Uccello! Uccello! } \\
\text { Uccello! }\end{array}$ \\
\hline \multicolumn{2}{|c|}{$\begin{array}{l}\text { 4. 'No ifs, no ands, or buts' D'amore o d'accordo (Series 3; Episode 5) } \\
\text { Samantha is talking about her Afro-American lover. }\end{array}$} \\
\hline $\begin{array}{l}\text { Samantha: "...he happens to have the } \\
\text { biggest black cock" } \\
\text { Charlotte: "Afro-American cock !" } \\
\text { Samantha: "[...]in fact he has the } \\
\text { biggest, black cock!" }\end{array}$ & $\begin{array}{l}\text { Samantha: ...e si fa il caso che abbia } \\
\text { il più grande uccello nero! } \\
\text { Charlotte: Si dice grande uccello } \\
\text { afro-americano! } \\
\text { Samantha: [...] infatti ha il più } \\
\text { grande uccello nero! }\end{array}$ \\
\hline
\end{tabular}

Firstly, the most neutral term 'penis', (example 1), is significantly abated to a pronominal form i.e. 'it', while the stronger word 'dick' is reduced to uccello (example 2). However, as can be seen, even when the stronger term 'cock' occurs in the original (examples 3 and 4), it too is mitigated to uccello in Italian. Example 3 is supposed to be humorous in intent. Miranda repeats the term 'cock' five times in order to excite her partner. But she utters the word with a comic, rather than sexy, expression on her face. The term uccello in the dub accentuates the comic effect, although possibly for the wrong reason. Miranda's lover is aroused by the repetition of the term 'cock'. I would argue that repeating uccello five times, is unlikely to create the same effect. Similarly, in example 4, the fact that 'cock' is colligated 
with 'black' and 'Afro-American', renders the whole exchange both more comic and more shocking. Again, the choice of the term uccello weakens both the comic and shock effect.

Table 4 Compensation

5. 'The Awful Truth' La verità fa male...? (Series 2; Episode 2)

During counseling Samantha finally admits to the therapist and, to her partner, that he has a small penis.

Lover: "Maybe your vagina's too big!" $\quad$ Lover: Forse la tua vagina è troppo Samantha: "What can I do...I need a big dick!" grande.

Samantha: Che ci posso fare...mi serve un cazzo più grande!

6. 'Running with Scissors' Il momento migliore, il momento peggiore (Series 3; Episode 11)

One of Samantha's lovers is telling her how excited he is.

"I got a hard on just looking at you" $\quad$ Il cazzo si è rizzato solo guardandoti.

However, the translational choice of compensation illustrated in Table 4, produces a very different effect. While the term 'dick' is used in the original - not the strongest choice for denoting male genitalia in English, the Italian dub for once, ignores the usual choice of uccello and prefers the more powerful cazzo, thus compensating for mitigations (and deletions of other terms) elsewhere in the episode (and, indeed, series as a whole). Similarly, in example 6, the colloquial expression for having an erection 'to get a hard on' is augmented in the dub by preceding it with the stronger Italian term for the male organ: il cazzo si è rizzato (i.e. 'my cock got a hard on').

\subsubsection{Female genitalia}

The term 'pussy' is usually mitigated in translation to childlike terminology. Table 5 , illustrates how it is translated with passera - a term commonly used in central and northern Italy, and patatina (lit. 'small potato') a word used by mothers talking to little girls.

Table 5 Mitigation in the naming of female genitalia

7. 'Sex and the City' Le donne, il sesso e gli uomini (Series 1; Episode 1) Charlotte is trying not to name her vulva.

Carrie: "Pussy?" $\quad$ Carrie: Passera?

Charlotte: "I hate that word!" $\quad$ Charlotte: Detesto quella parola! 


\begin{tabular}{|c|c|}
\hline \multicolumn{2}{|c|}{$\begin{array}{l}\text { 8. 'The Awful Truth’ La verità fa male...? (Series 2; Episode 2) } \\
\text { Miranda is in bed with Aaron.. }\end{array}$} \\
\hline $\begin{array}{l}\text { Aaron: "Oh baby, I just love the way } \\
\text { your pussy feels." }\end{array}$ & $\begin{array}{l}\text { Aaron: Oh piccola, non } \\
\text { piace la tua patatina }\end{array}$ \\
\hline \multicolumn{2}{|c|}{$\begin{array}{l}\text { 9. 'No ifs, no ands, or buts' D'amore o d'accordo (Series 3; Episode 5) } \\
\text { Samantha's lover's sister tells her to leave him alone, Samantha puts up a fight. }\end{array}$} \\
\hline $\begin{array}{l}\text { Sister: "Get your little white pussy } \\
\text { away from my brother." } \\
\text { Samantha: "Get your big black ass }\end{array}$ & $\begin{array}{l}\text { Sister: Tieni la tua fichetta Bianca } \\
\text { lontana da mio fratello. } \\
\text { Samantha: Tieni quel culone nero } \\
\text { lontano da me. }\end{array}$ \\
\hline \multicolumn{2}{|c|}{$\begin{array}{l}\text { 10. 'The Power of Female Sex' Il giusto scambio (Series 1; Episode 5) } \\
\text { Charlotte visits the home of a famous artist to find all that all his latest paintings } \\
\text { are of female genitalia. }\end{array}$} \\
\hline Artist: "The Cunt!" & $\begin{array}{l}\text { Artist: La Fica! } \\
\text { Artist's wife (to Charlotte): } \\
\text { Scommetto che Lei ha una bellissima } \\
\text { fica! }\end{array}$ \\
\hline \multicolumn{2}{|c|}{$\begin{array}{l}\text { 11. 'Don't ask, don't tell Nessuna domanda, nessuna risposta (Series 3; } \\
\text { Episode 12) } \\
\text { Samantha is trying on her bridesmaid's dress, it is too short for Charlotte's } \\
\text { taste. }\end{array}$} \\
\hline $\begin{array}{l}\text { Charlotte: "Is it my turn to ask you not } \\
\text { to wear your dress around your see- } \\
\text { you-next-Thursday?" } \\
\text { Samantha: "My what?" } \\
\text { Charlotte: "C-U-Next..." } \\
\text { Samantha: "Tuesday?" }\end{array}$ & $\begin{array}{l}\text { Charlotte: E davvero troppo chiederti } \\
\text { di non mettere in mostra la tua ti- } \\
\text { obbedisco con-passione? } \\
\text { Samantha:La mia cosa? } \\
\text { Charlotte:...ti-obbedisco-con- } \\
\text { passione? } \\
\text { Samantha: TOPA? }\end{array}$ \\
\hline
\end{tabular}

Example 9 shows the word 'pussy' translated with fichetta. Now, fica is a fairly strong term for female genitalia, and probably the nearest functional equivalent to 'pussy', although, as a well known sketch by Roberto Benigni demonstrates, a series of stronger terms are to be found in regional varieties of Italian ${ }^{10}$. By reducing fica to fichetta the shock factor is significantly diluted. However, despite the general raciness of the series, the term 'cunt', "by far the strongest of genitaliarelated items" (Azzaro 2006: 38), is used sparingly and only to denote the organ itself - in other words, never as a form of abuse. When a well known artist reveals his masterpiece to Charlotte, a series of paintings depicting giant-sized vulvas entitled "The Cunt" ('The Power of Female Sex' Series 1; Episode 5) the effect is both comic and startling. The translational choice is fica, an Italian term which is in no way as strong as the English. Yet, Italian does have a number of highly taboo equivalents such as fregna (in the area of Rome); pucchiacca (Naples); sorca (Tuscany and Emilia) etc. But these terms are avoided - and quite rightly, as they may well be recognized only by speakers of a particular region. Nonetheless, 
translators avoid the option of the term figa - a sort of supra-regional highly taboo term in which a series of Italian informants claim that the ' $\mathrm{g}$ ' makes all the difference (cf. fica). Thus, we appear to have another illustration of self-censorship. Throughout the series, reserved Charlotte does not use such strong language, but she frequently adopts the euphemistic expression "the C-word". This becomes an unheard of Quella parola con la ' $f$ ' in translation. So, when Charlotte spells out the letters of 'cunt' in the air with her fingers as she utters "C-U-Next..." (example 11) and Samantha adds "Tuesday?", the result is admittedly a tricky translational problem as the humorous effect is also created by the visuals. The word is highly mitigated in the dub to topa - again almost a childlike word for female genitalia (lit. 'female mouse') in many parts of Italy, but considered taboo in Tuscany. There is no reason, apart from bowdlerization, not to replace it with figa.

\subsubsection{References to sexual activity}

\subsubsection{Sexual intercourse}

The term 'fuck' is used liberally throughout the series, often as a de-semantised intensifier, but mostly as a verb to refer to sexual intercourse (as opposed to its many uses as an expletive). In English, this verb is extremely forceful and, admittedly, finding a good solution in Italian is no easy task. However, it is normally moderated in the dub by means of either the verb scopare - 'bonk or screw' (example 12; Table 6) or else with farsi qualcuno - 'have someone' (example 14), two adequate choices to get the meaning across, but lacking in the power of the English verb. In example 13, Samantha says she is literally 'fucked'. The translational choice falls upon the past participle of the verb fottere. This choice was perhaps an obvious one, as fottuto/a is indeed etymologically very close to 'fucked', and, like English, in its past participle form, it is used as a vulgar way of expressing 'having been deceived' (cf. English 'screwed', 'fucked ' etc.) and the participle is not normally used literally - although in the infinitive, it can be arguably, the closest in terms of register to the English. However, in this context the English term is far less ambiguous than the Italian equivalent especially since, in the same utterance Samantha describes some of the positions she and her partner adopted the previous night, amongst which we have 'on his face' which presumably refers

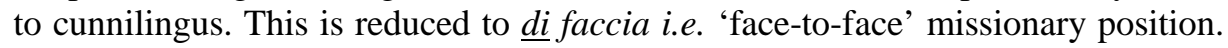
Worthy of attention is also example 15 in which the use 'fuck' is replaced (and diluted) by farlo ('do it') and although the same mitigation occurs in example 14, it is different and much weaker. This is due to the fact that in the former, we have a weak possiamo $+f a r+l o$ ('we can do it'), si+fa+ quell+ tizio ('has/makes (out with) that guy') in the latter. Finally, example 16 illustrates another frequent strategy applied to this verb in the dub, that of deletion, as 'fucking someone back to life' becomes simply 'bringing someone back to life'. 
Table 6 Dubbing the verb 'fuck'

12. 'Bay of Married Pigs' Singles \& Sposati (Series 1; Episode 3)

A group of friends are playing a party game.

"... which movie stars you would like $\quad$...vecchie star del cinema che avreste

to fuck when they were young." $\quad$ volute scopare quando erano giovani.

13. 'The valley of the twenty-something guys' Single è bello?

(Series 1; Episode 4)

a) Samantha: "I am so fucked. I mean

literally. I have been fucked every

way you can be. We did it with him

on top, with me on top...we did it

on his face."

14. 'The valley of the twenty-something guys'

Samantha is talking about one of her favourite films.

Miranda: "OK! Linda Fiorentino Miranda: Che scena! Linda Fiorentino

fucking that guy up against the che si fa quel tizio contro la rete di

chain-link fence."

Samantha: Sono fottuta. Sono stata scopata in tutti modi. L'abbiamo fatto

con lui sopra, con me sopra e di faccia.

15. 'The valley of the twenty-something guys'

Miranda refuses to have anal sex with her boyfriend.

\begin{tabular}{|l|l|l}
\hline Boyfriend: "Do we fuck the regular & Boyfriend: Possiamo farlo nella
\end{tabular} way?"

vecchia maniera?

16. 'Four women and a funeral' Strane opportunità Series 2; Episode 17

Miranda: "So you fucked him back to Miranda: Stai dicendo che l'hai life?"

riportato in vita?

Volta (2005) notes an example of deletion regarding references to coition; the first in 'The Fuck-Buddy' L'amico per il sesso (Series 2; Episode 14) in which Carrie, the narrating voice, says "We went back to my place for a quickie." Which becomes Poi andammo a casa mia - 'then we went back to my place' eliminating the sexual reference, as well as the omission of the morphemic use of 'fuck' in $\mathrm{Mr}$ Big's catchphrase "abso-fuckin-lutely" that is constantly reduced to assolutamente' (cf. Chiaro 2000b and Azzaro 2006: 47). It is also worth noting the moderation of the title of this episode from 'The Fuck-Buddy' to literally 'friend-forsex'.

\subsubsection{References to 'additional' sexual practices}

Naming of genitalia and references to coition can almost be considered one of the most naive taboo features dealt with in the series. In fact, there are episodes dealing with a plethora of other sexually related matter such as erectile problems, 
sexually transmitted diseases and fetishisms as well as activities such as oral and anal sex, sadomasochism and ménages à trios, to mention just a few of the practices tackled in the series. In this section we shall examine how, as for terms for genitalia and sexual intercourse, what I have labelled 'additional' sexual practices are also mitigated in translation. Space only allows me to discuss three of these practices, but the strategy of mitigation in translation is also a constant of those not mentioned.

\section{a) References to oral sex}

Oral sex is by far the most talked about non coital activity in the series, with very frequent occurrence of terms such as 'blow job', 'giving head', 'going down on' and 'eating out'. As discussed in 3.2, references to fellatio are normally mitigated. The same occurs with references to cunnilingus.

Table 7

'The Freak Show' Gli uomini sono tutti...strani? (Series 2; Episode 3)

17. Charlotte is dating a man whose sole interest is giving oral sex.

Samantha: "Mr Pussy...he loves $\mathrm{Mr}_{\text {Micia...gli piace da morire }}$

going down on women. He's a leg- leccarla alle donne...è incredibile a

end, he's amazing at eating pussy." mangiarti la micia.

Firstly, the name Mr. Pussy is reduced to a neutral Mr Micia - the translation is literal, but 'pussy' in Italian is monosemous and simply denotes felines. Secondly, 'going down on' is replaced with leccarla alle donne - literally 'licking it for women' which gets the message across albeit in uncertain Italian, as also occurs with the literal translation of the phrase 'eating pussy'. Similarly, the term micia is repeated in another collocation in translation of the item 'clit-tease' (Series 2; Episode 5), which becomes the nonce term: stuzzicamicia (literally: 'pussy cat teaser').

b) References to anal sex

It would appear that references to sexual activity related to the anal area are also mitigated. When Carrie 'talks dirty' to her boyfriend, (cf 'The Awful Truth') all is well until she tells him that she loves it when "I slip my finger in your ass." In Italian the body part is reduced to the more polite (childlike?) word sedere - "bottom'.

Again, in the episode in which Charlotte is asked by her boyfriend to partake in anal sex, she informs Carrie of his request over the phone; "He's asked me to have anal sex" she says. The camera homes in on a close up of Carrie's facial expression and she is seen drop what she is doing and go and console her friend. In Italian, Charlotte's utterance is deleted. The audience thus just sees Carries facial expression and watches her go to her friend's psychological rescue (thus saving Italian audiences from having to hear the word anal?). In the same episode, 
girls who engage in anal sex are described as "up the butt girls", utterance which becomes the more genteel quella che da via il sedere - "she who gives her bottom away'. The term of the same register i.e. culo, only occurs once.

c) References to urolagnia

An interesting example of mitigation is provided in the episode entitled 'Politically Erect' Politicamente Eretto in which Carrie strikes up a relationship with an eminent politician who asks her to indulge in urolagnia i.e. a fetish in which a person obtains sexual gratification from being urinated on. Now, I would like to argue that the original is already self-censured as the politician couches the request as follows: "I'll make you pee on me" which in Italian becomes ...fare la pipi adosso. Although the term 'pee' is genteel and in character with the politician, presumably in such a context, the stronger term 'piss' would have been more appropriate. Further alleviation occurs in the dub with the term pipi normally used by small children and informally by adults. Thus the edge of the request, already alleviated in the original, is lightened even further in Italian, with the effect of turning a sexual practice into something closer to children's talk. In fact, the collocation in Italian usually means to wet oneself i.e. to urinate inadvertently, something which small children typically do. Furthermore, when discussing the subject with her girlfriends, Carrie recounts the excuse she gave for not indulging in this practice. In English the excuse was "I told him I've just come, maybe another time." A strong cut occurs in Italian with Gli ho detto, l'ho appena fatta, magari un altra volta." (back translation: "I told him I had just done it, maybe another time.") Thus, the excuse shifts from orgasm to urination, still taboo, but presumably less so.

In another episode ('Three's a crowd; Sesso a tre - Series 1; Episode 8), a reference to a 'Golden shower' is reduced to una doccia di sudore - literally, a shower of sweat. In this particular example, it is not easy to ascertain whether the mitigation is deliberate or simply a case of the translator not knowing what a golden shower was and thus decided to keep on the safe side by avoiding any reference to urolagnia.

\subsection{Censoring the visuals?}

What emerges in this study is that although there are no cuts in the visuals, scenes including strong sexual content are mitigated through manipulation of the language - or rather, sounds the actors make. Although informants working in dubbing claim that bedroom scenes are alleviated by getting the characters to converse about something other than sex, no examples of this practice were found ${ }^{11}$. However, as discussed previously, the entire tone of the series is jauntier than the original, with dubbing actors often sounding less sexy than their original counterparts. It would appear that the quality of heavy breathing and sexual moaning during sex scenes is both reduced quantitatively, and in terms of voice quality of the actors. In a scene in 'The Awful Truth', in which Miranda is trying to excite her boyfriend by using risqué language there appears to be more heavy breathing in the original 
and her voice is lower and huskier than her Italian alter-ego. The same occurs in a scene in which she engages in telephone sex, the tone of the original is slightly more sober than the dub. However, most strikingly, such reduction occurs in scenes involving Samantha, the character who is most sexually active and has the highest number of partners. She is frequently portrayed in scenes having sex, in a number of positions and in variety of different ways. However, while she is a sexually active character, she is clearly also a comic character and, I would argue that in Italian, the comedic aspect is highlighted in such a way as to take the edge off the sex scenes. A convincing example of this suggestion can be seen in the episode in which Samantha engages in sex on a swing ('Running with Scissors'; Potevo, volevo, dovevo; Series 3; Episode 11). The screen features a full frontal nude shot of Samantha on a leather swing engaged in intercourse with a naked man. They are swinging to and fro as they copulate but, after a few seconds of moaning and heavy breathing, which, is arguably more jolly in the Italian dub, the couple fall off the swing. All we see are four legs akimbo pointing towards the ceiling. Where the original cuts to the next scene, the Italian contains additional laments of pain, followed by Samantha's very loud and histrionic, Aii aii "Ouch!". The effect is comic in both languages, but slightly more so in the dubbed version.

\section{Conclusions}

This paper has provided an overview of how taboo content is mitigated through dubbing in Italy. Although the use of censorship has been exemplified only in one series, namely $S a t C$, it seems that similar cuts and mitigations occur in other series and products too (see Bucaria, this issue). Of course, SatC is a particularly 'racy' series, but this is precisely why it was chosen for this case study. In other words, if taboo is mitigated in a series dealing with sex, then it is even more likely to be moderated in a series in which it is not the primary subject matter. Nonetheless, this discussion has simply touched upon the tip of an iceberg. SatC does not only include sexual taboo. The series also comprises diverse references to other areas of unmentionable subjects such as religion and diseases like AIDS and cancer, not to mention the profuse use of abundant swearing and cursing. Needless to say, mention of such matters is equally manipulated (see Ponza 2005 and Volta 2005).

Significantly, after examining the entire series, while we have established that the strategy of deletion is indeed implemented, it is mitigation which appears to be the norm for censorship. In other words, the taboo remains, but in a diluted form. Furthermore, from discussions with operators we can deduce that selfcensorship is most likely to be prevalent. Translators and adapters do receive some briefing, but it seems to be vague. When all is said and done, it is the dubbing director who has the final say. A script in the Italian 'dubbing cycle' constantly undergoes manipulation on its journey from translator to dubbing actor. If a dubbing actor feels a different utterance to the script is preferable, he or she is free to change it as long as the director agrees (Chiaro forthcoming b). Thus, it seems that choices are in the hands of individuals who are free to decide what Italian viewers 
will or will not find acceptable. However, whether Italian audiences are as straight laced as dubbing operators think they are, or would like them to be, remains to be ascertained.

\section{Bibliography}

Antonini, Rachele and Delia Chiaro (2005). "The quality of Dubbed Television Programmes in Italy: the Experimental Design of an Empirical Study." In S. Albertazzi, M. Bondi, G.Buonanno, N. Maxwell, C.Pelliconi and M.Silver (eds), Cross-Cultural Encounters: Linguistic Perspectives. Roma: Officina Edizioni, 33-44.

Bianchi, Diana (forthcoming). "Taming teen-language.The adaptation of Buffyspeak into Italian.”In Chiara Bucaria, Delia Chiaro and Christine Heiss, Updating research in screen translation.

Azzaro, Gabriele (2006). Four-letter films. Taboo language in movies. Roma: Aracne.

Chiaro, Delia (1996). "The Translation Game/La moglie del soldato - dubbing Neil Jordan." In Christine Heiss \& Rosa Maria Bollettieri Bosinelli (eds.) Traduzione multimediale per il cinema, la televisione e la scena. Bologna:CLUEB, 131-138.

Chiaro, Delia (2000a). "The British will use tag questions, won't they? The case of Four Weddings and a Funeral." In Christopher Taylor (ed.). Tradurre il Cinema. Trieste: Università degli Studi di Trieste, 27-39.

Chiaro, Delia (2000b). "Servizio completo? On the (un)translatability of puns on screen." In Rosa Maria Bosinelli, Silvia Bernardini, Marcello Soffritti and Christine Heiss, La Traduzione Multimediale. Quale traduzione per quale testo? Bologna:CLUEB, 27-42.

Chiaro, Delia (forthcoming a). "Introduction.” In: Delia Chiaro (ed.). Translating Humour: on the page, on screen, in interaction.

Chiaro, Delia (forthcoming b).'The Issue of Quality Standards in Screen Translation: Problems and Solutions." In Chiara Bucaria, Delia Chiaro and Christine Heiss, Updating research in screen translation.

Díaz Cintas, Jorge, (1999). "Dubbing or Subtitling: The Eternal Dilemma", Perspectives: Studies in Translatology, 7(1), 31-40.

Galassi, G. G. (2000). "“Fottiti amico.” In Christopher Taylor (ed.). Tradurre il cinema. Trieste: Dipartimento di scienze del linguaggio, dell'interpretazione e della traduzione, 3-8.

Hargan, Noleen (2006). "The foreignness of subtitles: the case of Roma, città aperta in English." In Nigel Armstrong and Federico M. Federici (eds.) Translating Voices Translating Regions. Roma: Aracne; 53-71.

Ivvarson, Jan (1992). Subtitling for the Media. Stockholm: Ljunglöfs Offset AB.

Munday, Jeremy (2006). "Style in Audiovisual Translation." In Nigel Armstrong and Federico M. Federici (eds). Translating Voices Translating Regions. Roma: Aracne, 21-36.

Pavesi, Maria (1994). "Osservazioni sulla(socio)linguistica del doppiaggio." In Raffaella Baccolini, Rosa Maria: Bollettieri Bosinelli and Laura Gavioli (eds). Il Doppiaggio Trasposizioni linguistiche e culturali, Bologna, CLUEB, 130-142.

Pavesi, Maria (1996). "L'allocuzione nel doppiaggio dall'inglese all'italiano", In Christine Heiss \& Rosa Maria Bollettieri Bosinelli (eds) Traduzione multimediale per il cinema, la televisione e la scena, CLUEB, Bologna, 117-130.

Pavesi, Maria and Annalisa Malinverno (2000). "Usi del turpiloquio nella traduzione filmica." In Christopher Taylor (ed.) Tradurre il Cinema. Trieste: Dipartimento del linguaggio, dell'interpretazione e della traduzione; $75-90$.

Ponza, Elisa (2005). Sex and the City: italiani e americani a confronto sull'umorismo a sfondo sessuale. Unpublished dissertation, SSLMIT, Università degli Studi di Bologna, Forlì.

Vandaele, Jeroen. (2002). "'Funny Fictions': Francoist Translation Censorship of Two Billy Wilder Films." In Jeroen Vandaele (ed.). Translating Humour. Volume 8, Number 2, 267-302.

Volta, Annalisa. (2005). Sex and the City: la censura dei dialoghi. Unpublished dissertation, SSLMIT, Università degli Studi di Bologna, Forlì.

Vandaele, Jeroen (2002). "Funny Fictions: Francoist Translation Censorship of Two Billy Wilder Films". The Translator 8(2), 267-302. 


\title{
Filmography
}

\author{
Ally McBeal (1997-2002) \\ USA, FOX \\ Directed by Davide E. Kelley \\ Beauty and the Geek \\ WB and UPN \\ Produced by Ashton Kutcher \\ Jason Goldberg \\ Nick Santora \\ Big Love (2006-present) \\ USA HBO \\ Produced by Mark V. Olsen and \\ Will Scheffer \\ Buffy the Vampire Slayer (1997-2003) \\ USA, WP and UPN \\ Directed by Joss Whedon \\ Desperate Housewives (2004-present) \\ USA, ABC \\ Directed by Larry Shaw and \\ David Grossman
}

Girls from the Playboy Mansion (2005-present)

USA, E!

Produced by Kevin Burns and Hugh Heffner

The L Word (2004-present)

USA

Directed by Ernest R. Dickerson and

Tony Goldwyn

Nip/Tuck (2003 - present)

USA, FX Networks

Directed by Ryan Murphy

The Simple Life (2003 - 2005)

USA, FOX

Bunim/Murray Productions

1 In Italy, popular series are normally premièred by Fox and subsequently re-screened for a wider and more heterogeneous audience when they are bought by state owned RAI that buys these products 'allinclusive' of translation. It thus stands to reason that issues of censorship need to be borne in mind well before the series arrives at RAI (Mario Paolinelli, dubbing director and founding member of AIDAC Associazione Italiana Doppiatori ed Addattatori Cine-televisivi [The leading Italian association for operators in the dubbing industry] personal communication.)

2 I am especially grateful to dubbing director and dialogue adapter Eleonora di Fortunato for her assistance in my quest in searching for the elusive 'black list' of forbidden words. Unfortunately, whenever she was close to finding it, she would discover that the hard disk on which the list had been stored had recently crashed or else the file had been mysteriously deleted. Such evidence leads us to suspect the likelihood of widespread self-censorship carried out by translators themselves.

3 The Cast Doppiaggio team of dubbing-translators was made up of Renato Cecchetto, Elisa Galletta, Cristina Giachero, Cristina Grado, Ruggero Busetti, Carla Vangelista, Tatiana Visonà, Laura Bacci, Carlo Cosolo and Cinzia De Carolis with Cinzia de Carolis and Maria Fiore directing the dubbing. $C V D$ dubbing-translators were Orietta Regina, Rosalba Castaldo and Vittorio Amandola while Claudio Capone, Solvejg D’Assunta, Cristiana Lionello, Sonia De Dominicis, Luigi La Monica and Renato Cortesi directed the dubbing.

4 I would like to express my gratitude to Luigi La Monica for dedicating his time to enlightening me on the hitherto untold norms regarding censorship in the Italian dubbing industry.

5 In Italy, it is not at all unusual that one single person to be responsible for more than one part of the entire dubbing process. In other words, within the process of dubbing a single product, the dubbingtranslator may also act over the voice of one of the original characters; a dubbing-actor may also be the dubbing director and so on. Chiaro has labeled operators covering more roles in the process of dubbing a single product "polyvalent figures" (Chiaro forthcoming b).

6 I would like to thank Roberta Pifferi for the information she so willingly supplied.

7 "Allora, riguardo alla sua domanda, non vi è una risposta precisa. Le battute sul sesso, così come le parolacce, vengono trattate diversamente di volta in volta. Le istruzioni in merito ci arrivano 
direttamente dal canale che commissiona il programma. Ci capitano serie, come ad esempio "The Simple Life" o "Beauty and the Geek" o "Girls from the Playboy Mansion" o mille altre, in cui ci viene permesso di lasciarle così come sono, anche se l'edulcorazione è sempre preferibile. Ci sono altri casi, il più eclatante dei quali mi è capitato non più tardi di un mese fa ("Extreme Russia"), in cui gli adattatori come me devono trasformarsi in AUTORI e inventarsi completamente battute intere per censurare i riferimenti al sesso. Una fatica...In linea di massima, comunque, è il canale che ci dà il TARGET a cui puntare e, in base a questo, le relative istruzioni per trattare i punti più problematici. Se dovessi fare un bilancio, le direi che il più delle volte le allusioni si conservano mentre le battute più esplicite, a volte anche grevi (gli americani sono maestri in questo!) vengono eliminate."

8 For detailed discussions of dubbese see Antonini and Chiaro (forthcoming).

9 Needless to say, 'vulgarity' is in the eyes, ears and personality of the beholder. My hypothetical scale appeals to the common sense of where and when such terms would be used.

${ }^{10}$ In 1983, during a live program broadcast by RAI, (Fantastico), Roberto Benigni lists 19 different terms for female genitalia.

${ }^{11}$ Eleonora Di Fortunato, personal communication. This alleged practice was also denied by Luigi La Monica. 